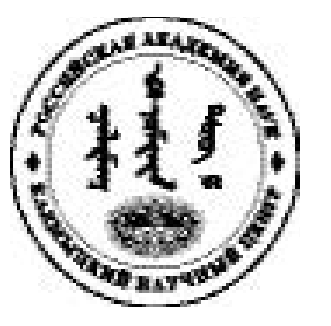

Published in the Russian Federation

Oriental Studies (Previous Name: Bulletin of the Kalmyk Institute

for Humanities of the Russian Academy of Sciences)

Has been issued as a journal since 2008

ISSN: 2619-0990; E-ISSN: 2619-1008

Vol. 14, Is. 4, pp. 722-742, 2021

Journal homepage: https://kigiran.elpub.ru

УДК / UDC 394

DOI: $10.22162 / 2619-0990-2021-56-4-722-742$

\title{
Нарративы «детей Сибири» о депортации калмыков. Интервью с В. И. Бадмаевым и А. Н. Овшиновым
}

\section{Эльза-Баир Мацаковна Гучинова ${ }^{1}$}

${ }^{1}$ Калмыцкий научный центр РАН (д. 8, ул. И. К. Илишкина, 358000 Элиста, Российская Федерация) доктор исторических наук, ведущий научный сотрудник

0000-0002-9901-0131. E-mail: bairjan@mail.ru

(C) КалмНЦ РАН, 2021

(C) Гучинова Э.-Б. М., 2021

Аннотация. Введение. Эта публикация посвящена депортации калмыцкого народа в Сибирь (1943-1957 гг.) и памяти об этом периоде среди калмыков, имевших личный опыт пребывания в ссылке. Она состоит из введения, двух интервью и комментариев к ним. Предлагаемые нарративы относятся к поколению калмыков, вывезенных в Сибирь в раннем детстве — в дошкольном возрасте. Цель публикаичи - выделение опыта детей Сибири как отдельной поколенческой страты с особым опытом испытаний и лояльностями: первой малой родиной становилась сибирская деревня, в которой проходила социализация ребенка. Кроме фактов о жизни в Сибири, которые своим разнообразием создают мозаику сибирской жизни калмыков, кроме рассказов о чувствах и переживаниях взрослеющих детей и их родителей, автору важно проследить, какими выражениями и вербальными формулами, какими сюжетами и ассоциациями создается спонтанный нарратив о годах депортации именно у «детей Сибири», и как использован язык травмы, который возникает при любом повествовании о травматическом событии. Материалы и методbl. В статье использованы материалы расшифрованных текстов спонтанных интервью, полученных автором в 2006 г. у В. И. Бадмаева и в 2017 г. у А. Н. Овшинова. Они анализируются с помощью метода дискурсивного анализа. Результать исследования свидетельствуют, что дискурсивные стратегии этих двух нарративов говорят об их позитивном характере. Автор аргументированно показывает, что «детей Сибири» можно выделить как группу депортированных, исходя из их опыта депортации и памяти об этом. Тексты интервью и комментариев будут интересны всем исследователям депортации калмыков и памяти об этом периоде.

Ключевые слова: депортация, калмыки, репрессии в СССР, Великая Отечественная война, Сибирь, память, нарратив, язык травмы

Благодарность. Исследование проведено в рамках государственной субсидии - проект «Комплексное исследование процессов общественно-политического и культурного развития народов Юга России» (номер госрегистрации: АААА-А19-119011490038-5). Автор выражает благодарность своим расссказчикам - В. И. Бадмаеву и А. Н. Овшинову. 
Для цитирования: Гучинова Э.-Б. М. Нарративы детей Сибири о депортации калмыков. Интервью с В. И. Бадмаевым и А. Н. Овшиновым // Oriental Studies. 2021. Т. 14. № 4. С. 722-742. DOI: $10.22162 / 2619-0990-2021-56-4-722-742$

\title{
'Children of Siberia' and Their Narratives about the Kalmyk Deportation: Interviews with V. Badmaev and A. Ovshinov
}

\author{
Elza-Bair M. Guchinova ${ }^{1}$ \\ ${ }^{1}$ Kalmyk Scientific Center of the RAS (8, Ilishkin St., 358000 Elista, Russian Federation) \\ Dr. Sc. (History), Leading Research Associate \\ 0000-0002-9901-0131. E-mail: bairjan@mail.ru \\ (C) KalmSC RAS, 2021 \\ (C) Guchinova E.-B. M., 2021
}

\begin{abstract}
Introduction. This publication is devoted to the issues of deportation of the Kalmyk people to Siberia (1943-1956) and the memories that the individuals have of their traumatic experience of the exile period. It consists of an introduction, two interviews, and comments on them. The narratives belong to Kalmyks who were of preschool age at the time of Siberian exile. The purpose of the publication is to focus on "children of Siberia" as a separate generational stratum, with their own specific experiences and loyalties; Siberian villages, sites of their socialization, becoming their homeland. Of relevance are the facts that contribute to the mosaic of the Siberian life of Kalmyks and the stories shedding light on the feelings and experiences of children growing up in Siberia. Also, the author was interested in analyzing the expressions and verbal formulas, plots and associations that create the protagonists' spontaneous narratives, and the ways the language of trauma, which arises in any narrative of the traumatic event, is used in the material under study. Data and methods. The interviews were taken by the author from V. I. Badmaev (2008) and from A. N. Ovshinov (2018); presented in the form of transcribed texts, these are examined via the method of discourse analysis. Results. The discursive strategies of the two narratives indicate their largely positive character. The author shows that, for their specific exile experience, the "children of Siberia" should be singled out into a separate generational stratum. The material will be of interest to the student of the Kalmyk deportation history and the people's memory of the exile.

Keywords: deportation, Kalmyks, repression, the Great Patriotic War, Siberia, memory, narrative, the language of trauma

Acknowledgements. The reported study was funded by government subsidy - project name 'Sociopolitical and Cultural Development of South Russia's Peoples: Comprehensive Studies of Respective Processes' (state reg. no. AAAA-A19-119011490038-5). The author expresses gratitude to the interviewees - V. I. Badmaev and A. N. Ovshinov.

For citation: Guchinova E.-B. M. 'Children of Siberia' and Their Narratives about the Kalmyk Deportation: Interviews with V. Badmaev and A. Ovshinov. Oriental Studies. 2021. Vol. 14 (4): 722-742. (In Russ.). DOI: 10.22162/2619-0990-2021-56-4-722-742
\end{abstract}

\section{छ}

\section{Введение}

Депортация калмыков - важная тема в истории калмыцкого народа, повлиявшая на все стороны жизни калмыков. Память о ней во многом зависит от того, к какому поколению принадлежит рассказывающий об этом. Обычно выделяют «поколение 1», которое было выслано и провело 13 лет в Сибири, «поколение 2», которое родилось после возвращения, и «поколение $3 »-$ так называемые «внуки Сибири» (см.: [Шевенова, Гучинова 2005]). 
В этой публикации я хочу выделить «детей Сибири» - поколение, которое имело свой специфический депортационный опыт. С одной стороны, это были дети, выселенные в раннем дошкольном возрасте, поэтому они не почувствовали в полной мере лишений дороги, о них заботились старшие. Несмотря на перенесенные семейные трудности в первые месяцы и годы, дети часто их не помнят. В то же время они совсем не помнили Калмыкию, не скучали по ней, а родиной для них стала Сибирь. Возвращаясь в Калмыкию, они осваивали ее, знакомясь с ней и привыкая к ней, вспоминая и скучая по сибирской земле - своей малой родине.

К этому поколению можно отнести В. И. Бадмаева, который родился перед войной, в 1937 г., и А. Н. Овшинова, родившегося в 1942 г., в период недолгой оккупации Западного улуса. Немцев их семья не видела, но документ о рождении на немецком языке сохранился.

Несмотря на принадлежность к одной возрастной когорте, разница в 5 лет показывает разные опыты в рамках одного «сибирского детства». Валерию Бадмаеву, отец которого погиб на фронте в первые месяцы войны, оказавшемуся в Сибири младшим из двух братьев-школьников, в семье, в которой работала одна мама, пропадая в школе с утра до вечера, а дома оставались сестренка и слепая бабушка, пришлось не просто. Его рассказ о детстве почти весь полон воспоминаний о работе по хозяйству: все лето проходило в труде, в труде, в труде.

Алексей Овшинов был самым младшим в полной семье, в которой фронтовик по счастливой случайности в тот роковой день был на побывке дома. Старшие братья и сестра, любящие родители жалели мальчика, у которого рано проявились проблемы со зрением, но и он помнит не только велосипед и собаку Сильву, но и свой труд на огороде и по хозяйству.

Мои собеседники - известные в Калмыкии люди. Валерий Ишляевич Бадмаев долгие годы работал в области энергетики Калмыкии, Алексей Николаевич Овшинов - один из первых социологов республики, много лет преподает в Калмыцком государственном университете. Предлагаемые два интервью были свободными, с записью на диктофон. Разговор с В. И. Бадмаевым прошел в Элисте в 2006 г., с А. Н. Овшино- вым — в 2017 г. в Элисте. Тексты интервью были авторизованы в 2021 г. В. И. Бадмаев добавил в расшифрованный текст интервью имена калмыков, которые вместе проживали с Бадмаевыми в сибирских селах. Методика опроса описана в предыдущих публикациях [Гучинова 2005; Гучинова 2019].

\section{В. И. Бадмаев}

Детство свое помню очень плохо, в основном - только со слов нашей мамы. Да и она не очень охотно вспоминала о том страшном периоде в жизни нашего отечества и нашей семьи в частности.

Отец мой, Ишля Манджиевич Бадмаев, родился 27 января 1906 г. в селе Актюбеевка Приволжского улуса. Он должен был быть репрессирован в 1938 г. В то время он работал вторым секретарем Калмыцкого обкома партии, председателем Верховного Совета, также первым председателем Союза писателей Калмыкии. Однако его не успели арестовать. Кто-то позвонил ему ночью и предупредил: «Ишля, за тобой придут». Он сразу все понял и самолетом обкома вылетел в Москву в 4 утра. Это было летом 1938 г. А в 6 часов утра к нам пришли энкавэдэшники, чтобы его арестовать. Мама сказала, что он улетел в Москву, за ним вдогонку они вылетели самолетом. Как выяснилось позже, на отца был написан донос. Его обвиняли в связи с Анджуром Пюрбеевым, Антоном Амур-Сананом, которых уже расстреляли в сталинградской тюрьме.

Как мне рассказывала моя мама, Нямиш Шургановна Чудутова, 1910 г. р., в то время было такое положение: представители местных органов НКВД не имеют права производить арест на территории Москвы, поэтому отцу удалось сразу с самолета поехать на прием к М. И. Калинину. Тот внимательно выслушал его и сказал: «Я знаю, что Вы хороший марксист, тем более Вы сами учились и преподавали в Институте красной профессуры». Михаил Иванович предложил ему остаться в Москве и обещал помочь с работой и квартирой. Таким образом, отец стал сначала работать преподавателем, а затем и заведующим кафедрой марксизма-ленинизма в Институте золота и цветных металлов. Квартиру ему выделили на Большой Пироговке, где и поселились мы всей семьей: папа, мама, старший брат Гера и я, а позднее и наша младшая сестренка Кермен (Кармен). 
Когда началась война, отца дважды вызывали в ЦК с предложением отправиться в ЦК Узбекистана для организации работы тыла. Однако отец с его очень плохим зрением пошел добровольцем на фронт. Его назначили комиссаром первого ополченческого московского полка, состоявшего в основном из представителей московской интеллигенции. Состав был направлен на Ленинградский фронт в конце августа 1941 г. Мы же писали, искали его... Но, как потом стало известно, их состав, как и все составы, направленные на Ленинградский фронт, немцы тщательно бомбили. Следов мы так и не нашли, а мама получила извещение о том, что отец пропал без вести.

В начале войны он успел отправить нас в Элисту. Когда немец подходил к Элисте со стороны Ростова, все бежали в сторону Астрахани. Мне было 4 года, я помню, как мы ехали на арбах, на подводах, запряженных волами. Лето, 40-градусная жара, воды и еды нет. Мы ехали с мамой, братом Генрихом, бабушкой Мацак Чудутовой и младшей сестренкой Кемой двух лет.

Как рассказывала мама, мы остались самыми последними из семей ответственных работников, успевших эвакуироваться в сторону Астрахани. И мы пошли через степь. Хочинов Алексей, редактор газеты «Улан хёёч» (отец Лидии Куриновой, ее мама - Ушкинова Мильчуха), довез нас до каравана. Помню, как немецкий самолет на бреющем полете летал прямо над нашим караваном беженцев. Я помню только красное смеющееся лицо летчика. Все разбежались, думали, что он будет стрелять. Скот перепугался. Мама рассказывала: меня искали-искали, а я чью-то туфлю схватил и куда-то убежал... Потом они меня нашли.

Жили мы [в эвакуации] в Актюбеевке Астраханской области. Когда летом 1943 г. была освобождена от фашистских захватчиков Элиста, мы вернулись в Калмыкию, в Башанту — на родину нашей мамы.

И выселяли нас из Башанты - это я хорошо помню. 28 декабря 1943 г. - страшная дата в жизни калмыцкого народа. Ночью стук в дверь. Бабушка у нас была слепая. Заходят двое военных. Нам дали пять минут на сборы. Что там за пять минут мама успела, то и взяли. А все вещи так и остались в московской квартире. Посадили нас в громадные машины с тентами - студебек- керы и повезли в Сальск. Там нас погрузили в вагоны, предназначенные для перевозки скота, и повезли, оказывается, в Сибирь. Во что я был одет, не помню, но мы мерзли и голодали - это я помню хорошо. Когда ехали уже по территории Урала, стало еще холодней. Вагон не отапливался. Не знаю, как нас мама сберегла, но люди действительно замерзали. Ни еды, ни тепла. Единственно, помню, у мамы волосы были густые и длинные, а сестренка Кемочка была маленькая. Мама ее укрывала ими - держала сестренку под волосами, чтобы ей потеплее было. В нашем вагоне были окоченевшие трупы - на остановках их выносили. И потом их просто выбрасывали. Я не помню, сколько суток мы ехали, но выдержали.

Нас привезли на станцию г. Омск. Холод страшный, снег глубокий. Нас встречали подводы-розвальни. Солома, сено там. Нас повезли. Не помню, сколько от Омска, но привезли в большой амбар, тоже не отапливаемый. Но там было много соломы. В этой соломе мы жили и ждали, куда же нас поселят. Попали мы на 3-ю ферму совхоза № 54 Кагановического района Омской области. Здесь жили также: Нимяшевы (Петр Доржинович Нимяшев был позже председателем колхоза имени XXII партсъезда Городовиковского района); Эрдненовы, у них был сын Владимир; Айдаровы Александр и Наталья, их дочь Валя и приемный сын - русский рыжий мальчик, наверное, 1935 г. р., имени не помню; Хачиновы; дед Дорджи - большой умелец, шорник, делал всю сбрую для коня; был одинок, без семьи. На 1-й ферме жили: Джиджиковы; их сын Владимир и дочь Анна; Нембриковы Эрдни и Домна с дочерьми: Лидией, Светланой, Валентиной.

Мама в свое время окончила Астраханское педучилище. А там, куда нас привезли, учителей не было. Комендант, узнав по документам, что она учительница, да мама и не скрывала, направил ее работать в начальную школу. На ферме нам дали комнатку в бараке. Там и поселились мама, наша слепая старенькая бабушка и нас трое детей.

Сибиряки - добрый, отзывчивый народ. Вначале они были напуганы, там ведь распустили слухи, что едут людоеды - они нам это потом сами рассказывали. Кроме того, их удивило, что среди репрессированных были только женщины, старики, дети и ни одного мужчины. 
А мужчины, отцы и деды наши, воевали на фронте. И как они воевали? Не могу не сослаться на опубликованную Министерством обороны СССР статистику о Героях Советского Союза, награжденных за подвиги в период Великой Отечественной войны, согласно которой на первое место по количеству Героев Советского Союза в расчете на 1000 человек вышли осетины. А калмыки оказались на втором месте, но напомню, что указ Верховного Совета СССР о депортации калмыцкого народа вышел 28 декабря 1943 г., согласно которому в течение суток весь народ был снят с мест постоянного проживания и отправлен в скотных вагонах в Сибирь. Причем предполагалось дисперсное его расселение по всей территории Сибири. Омская, Тюменская, Новосибирская, Иркутская области, Красноярский и Алтайский края, Салехард и Сахалин - вот места поселения степняков-калмыков, численность которых, согласно предвоенной переписи, составляла 110 тысяч (точнее 134400 чел.).

Справедливость требует учитывать и тот факт, что, согласно данному указу, все калмыки-фронтовики были сняты со всех фронтов в январе 1943 г. и отправлены в Широклаг, откуда вернулись единицы. Следует отметить, что к чести некоторых отцов-командиров они не сдали своих воинов-калмыков. И до сих пор открываются новые и новые факты героического поведения наших земляков на фронте в 19431945 гг., но уже без наград. И кто знает, сколько еще Героев Союза могло бы быть у нашего народа. Например, 2-3 года тому назад разыскали 25-го защитника Дома Павлова в Сталинграде - Гарю Бадмаевича Хохолова, долгое время значившегося в списках как Неизвестный солдат.

Очень тяжело пережили мы первую зиму депортации. Голод косил калмыков. Репрессированным разрешили копать на совхозном поле картошку, оставшуюся с прошлого года. И мы взяли лопаты и копали мерзлую картошку. Мне было шесть лет, брату Гере пошел девятый год. И калмыки копали это поле, искали остатки мерзлой картошки. Мы с братом накопали ведро этой картошки, правда, изрыли много земли. Принесли домой, и мама нажарила лепешек. Мне до сих пор кажется, что это были самые вкусные и сладкие лепешки.
В 1944 г. я пошел в школу. Нас в классе было всего несколько человек. Мама была моей первой учительницей. Чернил не было, тетрадок не было. Я не знаю, где что она находила. Она, видимо, из старых книг страницы вырывала для нас, пяти учеников первого класса, свекольный сок в блюдечко выжимала, и этим красным соком мы писали. Свои первые буквы я написал свекольным соком.

Чтобы меня дразнили — такого я не помню. Там, где мы жили, были две семьи поволжских немцев, потом, уже в 1949 г., латышей привезли. Они приехали семьями со всем домашним скарбом. Богатые!

Мы, дети, дружно играли в лапту, футбол. Но в основном мы трудились. Сколько себя помню, по хозяйству, в огороде, в совхозе вся работа была на наших детских плечах. То свеклу, то турнепс полоть. То картошку совхозную окучивать, то свою. А сено заготовить для коровы! И дрова тоже! Чуть подросли, нас стали сажать на сенокосилки, на грабли конные. И так все лето проходило - в труде, в труде, в труде.

Когда четвертый класс окончил, встал вопрос: как быть с учебой? Средняя школа была только на центральной усадьбе. А наши родственники - Мутл Баранович Буринов и его жена Хавра Сареевна Курноскина жили в том районном центре, в селе Красноярка Омской области. И мама умудрилась получить у коменданта разрешение отвезти нас с братом к ним на учебу.

Мамин дядя Мутл Баранович Буринов был мужчиной высокого роста и крепкого телосложения, в прошлом борцом, чемпионом Ставропольской губернии. Он знал калмыцкие обычаи, и руки у него никогда не отдыхали. Многому научились мы с братом в этой семье. Мутл Баранович принимал участие в Гражданской войне и Великой Отечественной войне. Один из немногих солдатов-калмыков, свой боевой путь он завершил в Берлине. Имел боевые награды, но никогда не показывал их, очевидно, чтобы не подвести своих отцов-командиров.

Жили там мы у дяди с тетей, как дома. Тетя Хавра всегда по утрам варила нам калмыцкий чай. Настоящей заварки не было, и мы с братом Герой собирали в лесу листья диких яблонь. Вначале черный чай пили, утром рано ходили в школу. Школа была с 8 утра. По 5-6 уроков. Находилась недале- 
ко, в 1 км от дома. Я пошел в 5 класс, а мой брат Гера там уже учился. На всю жизнь мы с братом сохранили благодарное отношение к этой семье.

У нас с Герой была обязанность делать заготовки продуктов на зиму. Картошку мы сажали, каждой семье совхоз выделял по 30 соток пахотной земли за пределами поселка. Там мы и выращивали картошку. И все лето - прополка, окучивание, правда, не поливали мы ее никогда. В бараке, где мы жили, у нас был подпол. Его мы забивали полностью - мешков до 40 туда входило. И на улице у каждой семьи был утепленный погреб. Его мы набивали тоже картошкой, утепляли соломой — и на зимнее хранение. За зиму мы и подпол, и погреб полностью опорожняли - только на картошке и жили.

А летом заготавливали ягоды и грибы грузди, белые, подосиновики, подберезовики, опята. Мы с местными ребятами ходили, они нас учили, что можно кушать и как. Мухомор сразу видно. Мы варили грибы, жарили. Летом хорошо: как в лес пойдешь, там и ягоды разные, саранка, пучки. Всем этим наедаешься. Саранка - растение типа луковицы. Пучки - большое растение, сердцевина мягонькая, мы шкурку отдирали и ели. После школы быстрее домой. Делаешь уроки и помогаешь по хозяйству. Ходили в лес, заготавливали дрова, сено косили. Мамин дядя козу купил. Коза молоко давала, мы ее подкармливали.

Я, кажется, в седьмом классе учился, не помню точно, мне было лет 13, наверное. В лесу всем выделяли делянки - сухостой. Мама говорит: «Нам делянку выделили, тебе лесничий покажет». Поехал он на коне, я с ним рядом пешком, показал мне нашу делянку: «Вот ваша делянка, надо сухостой вырубать». Мама взяла на ферме у управляющего подводу, двух быков и телегу. Я этих двух быков запряг и поехал в лес. Приехал на свою делянку. Начал рубить. Пока с утра было прохладно, вроде ничего. Я уже много нарубил этого сухостоя, вытащил на опушку и загрузил телегу. Уже полдень. Тепло. Овод начал беспокоить быков. Они вначале головами мотали, хвостами. А потом быки - хвост трубой - как пошли по опушке леса с телегой! Понеслись в заросли тальника, местность болотистая. Бричка уперлась в один пень, и быки остановились. Конечно, я тогда с ними замучился. Снова разгрузил бричку. После полудня, когда жара спала и овод немного затих, с величайшим трудом, еле-еле я вытянул быков оттуда. Еле бричку развернул. Опять все это погрузил. Потом поехал туда, где заготавливал, и загрузил доверху воз. Домой приехал только поздно вечером. Мама говорит: «Где ты так долго был? Я уже хотела за тобой посылать кого-нибудь». Я говорю: «Да так случилось, что быки взбесились от овода».

Мы как-то понемногу обживались, маме как учительнице зарплату давали. Мы первой овечку приобрели, Сонькой ее назвали, кур купили, сарай построили. Появился у нас и песик Кузя, ведь хозяйство надо охранять. Потом уже и корову Розу приобрели. Всем в совхозе выделяли покос. Сено для Соньки и для Розы косили мы втроем Гера, мама и я.

В 1945 г. нас почему-то перевели в соседнюю деревню. И в ней - я хорошо помню - кто-то скачет на коне вдоль деревни и что-то кричит - не поймешь. Подъехал ближе, стало ясно, он кричит: «Войне - конец! Победа!». Все выскочили на улицу, все кричат, кто плачет, кто смеется.

В то время жили все дружно, подлостей друг другу не делали. Все время с теплотой и благодарностью вспоминаешь о Сибири и сибиряках. Как так можно было поступить с нашим народом, ведь наше старшее поколение защищало родину, дралось с фашистами, а тут такую подлость сделать - все население выслать на гибель в лютую стужу. Выжили благодаря сибирякам. А когда слышу: вот Сталин то, вот Сталин войну выиграл... А ведь воевали-то и гибли простые люди и на их трупах держались знамена Победы.

Когда Сталин умер, я учился в 9 классе. Мы сидели за одной партой с Сашей Коровкиным. Мы были веселые. Тут такое горе все плачут. А мы начали смеяться, всё хохочем и хохочем. На траурную линейку нас построили. А нам смешинка в рот попала, и мы не можем остановиться. Пальцем в бок ткни, и я хохочу. Нас с ним выгнали с траурной линейки. Еле отсмеялись.

Наступил 1954 год. Вот и 10 классов позади. Школа наша была хорошая, учителя были замечательные люди, любившие свои предметы и своих учеников, почти все из которых росли без отцов. Литературу и русский вел Мишин Михаил Трофимович. Книг 
в основном не было, учебников не хватало. Всю поэзию он читал нам наизусть. А роман «Война и мир» Л. Н. Толстого достался мне только на одну ночь. Наш педагог привил нам на всю жизнь глубокую любовь и уважение к литературе и языку. А любовь к математике взрастила в нас Игнатенко Анна Николаевна. Благодарен ей за это! Немецкий язык вел Маевский Роберт Карлович, тоже репрессированный, волжский немец. Он сумел помочь нам понять богатство и красоту языка Гейне, Гете, Шиллера.

Все мы, кто окончил нашу школу в селе Красноярка, с искренней теплотой вспоминаем всех своих учителей. Благодаря им, у нас была очень хорошая подготовка, в основном все выпускники нашей школы поступали в институты.

Нам, калмыкам, было разрешено учиться только в сельскохозяйственных и ветеринарных институтах. В Омске был и тот, и другой. Наше село находилось в 40 км от Омска.

Мой брат Гера в 1952 г. поступил на мехфак Омского сельскохозяйственного института им. Кирова. Через два года и я окончил 10 классов. Я решил поступать в машиностроительный институт. Это решение созрело потому, что в летнее время я работал в нашем совхозе на сенокосилках, a c 8 класса работал уже на комбайне. Тогда я впервые заработал 800 рублей, и мама тогда купила мне хорошее пальто, а так я в фуфайке ходил. Я уже в механике кое-что начал соображать и работал на СТЗ - колесном тракторе, на НАТИ - гусеничном тракторе. У нас был совхоз молочного направления. Мы силос заготавливали.

Когда я окончил школу в 1954 г., я поехал в Омск и подал документы в Омский машиностроительный институт. А там не спрашивали, калмык ты или нет. Однако комендант каким-то образом узнал об этом и спросил меня: «Ты куда подал документы?» - «В Омский машиностроительный». — «Ты забыл, кто ты такой есть?»«Ну я калмык». - «Ну вот, раз ты калмык, тебе нельзя учиться нигде, кроме как в сельхозинституте или ветеринарном».

Я расстроился, конечно. Приехал домой и сказал, что пойду работать, буду брату помогать деньгами и все такое прочее. Мать в слезы: «Отец, уходя на фронт, меня очень просил, чтобы я дала вам всем высшее об- разование. Только учись». - «Нет, куда я хочу, меня не пускает комендатура».

Мама меня поругала, а я тоже уперся. Утром просыпаюсь, вижу - брат стоит. Мама сумела его каким-то образом вызвать. Спрашиваю: «Гера, ты что?». Он говорит: «Вставай, поговорим». Брат говорит: «Давай поступай к нам на мехфак. Там тоже техника, те же механизмы. Мать не расстраивай».

У калмыков есть такой обычай: если в семье умирает отец, то отцом для детей становится старший сын, а если умирает мать, то ее обязанности переходят к старшей дочери. Так было заведено и в нашей семье. Авторитет старшего брата Генриха для нас с сестрой был непререкаем. Поэтому я послушался брата, поехал сдавать документы в сельхозинститут.

Конкурс был семь человек на место. Я попал в 1-й поток. Экзамены начинались 1 августа. Мы сдали 5 экзаменов за 7 дней. И нам объявили: «Кто поступил, списки будут вывешены». Утром встаю после последнего экзамена, жил я в общежитии, иду, смотрю: я в списке поступивших! И висит объявление: «Кто поступил - в деканат срочно!».

Наш декан К. Беспалый говорит: «Дорогие товарищи, поздравляю вас с поступлением. Не знаю, кто где живет, но приказ такой: чтобы завтра все были здесь - завтра в 10 часов едете все на целину».

Благо, наш совхоз был в 12 км от Омска. Я - на молоковоз и домой. Маме даже не успел записку написать. Вытащил фуфайку, кирзовые сапоги, оделся по-рабочему. Утром уже был в институте. Пришли машины за нами, и нас — на целину. И вот мы с августа до самых заморозков поднимали целину в Омской области, в Русско-Полянском районе на границе с Казахстаном.

Коменданта звали капитан Сергиенко. Он нам не разрешал даже в соседнюю деревню сходить без его разрешения, но я так даже ни разу не расписался, хотя мне исполнилось 16 лет. Я все уклонялся и уклонялся. А потом уже началось послабление. Неприятно было, как будто я куда-то убегу. Мама просила расписываться. Мама всегда говорила: «Ничего никогда не говорить на людях, лучше вести себя тихо». Предупреждения были. Но иногда всё же приходилось и драться, если кто обидит. Обижали, гово- 
рили: узкоглазые, предатели. Но это было только поначалу.

А потом мы сдружились, всё было нормально. Народ в Сибири отзывчивый, добрый. Все мы внутренне понимали: что-то не то происходит в нашем отечестве, но вслух об этом не скажешь, могут донести коменданту. Возмущаться нельзя тоже, иной раз и хочешь высказаться, но смолчишь, помня наказ мамы. Остался все же отпечаток тех предупреждений - побольше молчать.

В селе Красноярка, где жил наш двоюродный дедушка, мамин дядя - Мутл Баранович, проживало несколько калмыцких семей. Это поселение мы называли «хотон», в нем жили Буринов Мутл Баранович и Курноскина Хавра Сареевна, сын Александр, у них жили и мы с Герой. Мутл Баранович - дядя нашей мамы (нахцх); Шириповы Бадма и Гуга; сыновья Ким, Иван, Александр, дочь (имя не помню); Ашиловы Овши и Груня; дети - Донара, Рая, Валера и племянница - Кая; Гендинова Гелана, ее дочери Раиса и Лидия; Насуновы Николай и Иван; Татниновы Тамара и Анатолий; Очировы Дорджи и Екатерина; Цеденова Мария; Азотовы, сын Анатолий; Хактинов Николай.

При нас, детях, точно ничего политического не отмечали и никаких разговоров не вели. Там же, где мама жила, мы никакие калмыцкие праздники не отмечали. Праздники калмыцкие мы отмечали в селе Красноярка, у маминого дяди, потому что там был калмыцкий хотон , все родственники по линии матери из Башанты, из Большедербетовского улуса.

Когда жизнь немного стала получше и даже муку можно было купить в магазине, вот тогда и начали справлять Зул и Цаган Сар. Верблюдов, барашков, овечек лепили из теста и выпекали.

Дома мы говорили по-русски, но с калмыками, что приходили в гости, мама разговаривала по-калмыцки. Я был и пионером, и комсомольцем. В комсомол мы вступили всем классом - пошли в райком комсомола, и нам всем выдали билеты. Мы, калмыки, учились хорошо. Учителя нас даже в пример ставили. Там с нами в школе учились Боря Чурюмов, Маша Цеденова, Белла Лапсина.

Многие наши ребята-калмыки, постарше возрастом, на русских девушках жени- лись, а Петр Нимяшев и Шучинов женились на сестрах-сибирячках. Они трудились хорошо, вообще к калмыкам относились с уважением. Калмыки, прирожденные животноводы, и в Сибири в основном за животными и ухаживали. Петя Нимяшев был главным конюхом. Кони у нас были хорошие - и тяжеловозы, и выездные лошади были, а коровы были племенные, очень хорошие высокоудойные. В основном калмыки в животноводстве и работали.

В 1949 г. наш совхоз взял по надоям молока первое место, вот тогда директору совхоза Нечаеву Ивану Федоровичу и зоотехнику Нечаевой Дине Кузьминичне были присвоены звания Героев соцтруда. А когда калмыки собрались уезжать на родину, директор прямо переживал, не хотел отпускать их: «Ну куда же вы едете, на кого вы нас бросаете? Кто тут будет вместо вас работать?». Однако родина потянула — все уехали в родные степи.

Зимой 1956 г. я был студентом, и в троллейбусе встретил калмыка, он в Омске жил, он сказал мне, что нас реабилитировали и восстанавливают республику. «Откуда знаешь?» - «Мне из Москвы передали».

А потом уже в 1959 г., когда я окончил институт, у нас же было распределение. И председатель ГЭК сказал: «Ну, товарищи, он же у нас калмык, все мы знаем, что республику восстановили. Пусть едет восстанавливать теперь свою Калмыкию». А остальных всех по распределению направили.

Учился я хорошо, получал стипендию 280 руб. Мы сразу же отдавали 140 руб. на талоны на трехразовое питание в студенческой столовой. Столовая наша была дешевая, потому что при институте было свое учебное хозяйство - и свиней, и коров своих держали, да овощная продукция своя была. Правда, мы подрабатывали. Студенты ведь как? Весной и осенью на Иртыше на разгрузке барж работали, а летом - на целине каждый год.

Студенческие годы вспоминаю всегда с удовольствием. С ребятами нашего курса до сих пор поддерживаем самые теплые отношения. До сих пор встречаемся и в своей любимой студенческой столовой. Обязательно отмечаем юбилейные даты, а в 2019 г. мы отметили 60 лет окончания института.

После поступления я сразу же сел на ДТ-54 (дизельный трактор), мы поехали за 
300 км от Омска и погнали новые трактора. На этих тракторах мы поднимали целину. Потом у нас был такой порядок на мехфаке. Весенняя сессия наступает. А сев был в мае. Если мы не успеваем сдавать экзамены, мы сразу едем на целину, сеем. Отсеялись, приезжаем, сдаем весеннюю сессию и уезжаем на целину готовить комбайны к уборочной страде, когда рабочий день длится по 10-14 часов. Мы уже тогда штурвальными все были. Комбайны были прицепные. До самой глубокой осени пока дожди, снега не выпадут, все убирали хлеб. И там зарабатывали. Не столько деньгами, сколько натуроплатой - мы много зерна зарабатывали. Ну, куда его девать, это зерно? Мы его сдавали государству по закупочной цене, и нам деньги давали. Тратили на одежду. Возвращались в институт. И начиналась учебная пора!

Репрессированные как-то между собой тепло относились друг к другу. Понимали, что те и что мы... А такого прямо явного давления, вроде превосходства со стороны местного населения, я не помню. Учеба работа, было не до девушек. Притом, когда мы поступили в институт, мы подружились несколько человек и дали клятву: пока мы на ноги не встанем, и лет по 30 нам не будет, не будем жениться. А мой друг Воронин на 4 курсе женился.

В школе и в институте я больше с русскими ребятами дружил. Калмыков же мало было. В нашем институте из калмыков учились на мехфаке Манцаев Владимир - 1-й выпуск, Бадмаев Генрих, я - Бадмаев Валерий, Надиев Эрдни; на зоофаке - Куринова Зинаида; на агрофаке - Джиджиков Владимир; на гидромелиоративном - Чурюмов Виктор; на мясомолпроме - Янжинова Мария.

В Омске была улица Луговая, там иногда зимой собиралась калмыцкая молодежь. Все общались между собой только на русском языке. Наверно, дело в том, что носители языка, наши бабушки и дедушки, не выдержав голода и холода первых двух зим, остались навечно лежать в сибирской земле. Бабушку нашу Мацак Чудутову мы тоже похоронили в Сибири. Она нашу сестренку Кему страшно берегла. Говорила, что она девочка и ей еще рожать детей.

Дисперсное расселение тоже сыграло свою негативную роль в угасании нашего языка. Ведь нас разбросали по разным селам и деревням, и расселяли по 5-6 семей. Если бы мы скученно жили бы, как в Алтайском крае жили кетченеровцы, - все в одном районе. Им повезло, у них и старшее поколение сохранилось. Поэтому они и язык хорошо сохранили...

Я с удовольствием пел в институтском хоре. С удовольствием пою и до сих пор. Увлекался фотографией. Когда я поступил в институт, мой дядя, мамин самый младший брат, Адольф Шурганович Чудутов поздравил меня и подарил мне фотоаппарат. Спортом не занимался, а у брата моего Генриха в институте был первый разряд по боксу и первый разряд по волейболу.

Брат матери Василий Шурганович Чудутов не был репрессирован. Сам он зоотехник, был танкистом, потом работал в Москве в органах государственной безопасности, оттуда его как калмыка освободили. Однако ему дали возможность выбора места жительства. Он поехал в Белоруссию директором совхоза, а оттуда - в Ошскую область директором совхоза. Он вызвал нашу маму в Киргизию в 1955 г.

В 1956 г. первой на родину уехала мама. Ее вызвали из Киргизии через Москву в оргкомитет. В оргкомитет входили тогда А. Б. Берденов, О. И. Городовиков, Б. О. Джамбинов, А. М. Джамбинов.

В первый раз я приехал в Элисту в 1958 г., тут вообще ничего не было. После таких городов, как Омск, было странно, что в нашей столице стоял всего лишь один красный дом ${ }^{1}$, а все остальные стояли разбомбленные и зияли черными глазницами пустых окон. Похоже, как калмыков отправили в ссылку, так здесь вся жизнь и остановилась.

С дипломом в 1959 г. я сразу поехал в Башанту, где уже работала мама вторым секретарем Западного райкома партии. К климату адаптировались быстро. Когда я приехал в Калмыкию, мне говорили: этот тайный осведомитель, этот... А мы тогда не чувствовали. У нас таких не было.

Паспорт я получил уже в Калмыкии. А до этого ходил со справкой, что я действительно есть я, и, когда я поступал в институт, я поступал тоже со справкой, паспорта у меня не было.

\footnotetext{
1 Здание общественного назначения.
} 
Все держалось на женщинах. Мало вернулось наших мужчин после фронта и после Широклага. Конечно, каждый старший калмык, кто с фронта пришел... Вот наш дед, мамин дядька - Мутл Баранович Буринов, он всю войну прошел, до Берлина дошел. А мамин младший брат, Адольф Шурганович Чудутов, командир пулеметного отделения, под Сталинградом был тяжело ранен, ему ногу оторвало. Все равно... Наши бабушки все время молились, молились, чтобы они вернулись.

Все наши ребята в Башанту вернулись с сибирскими женами, потому что в нашем селе девушек-калмычек на выданье не было. А подросшим парням надо было семьями обзаводиться, кстати, у нас все нормально воспринимали такие браки.

В семье мы часто вспоминали и до сих пор вспоминаем Сибирь, там же детство и юность прошли. Друзей много там осталось. В 2004 г. меня разыскали одноклассники и однокурсники. Мне позвонили однокурсники, говорят: Валера, еле нашли тебя. На июль планируем встречу - 45 лет выпуска института. А потом звонят одноклассники: собираем всех, кто 50 лет назад закончил Красноярскую школу. На эту встречу я поехал со своей женой, Наной Санджиевной Бадмаевой.

Нас так тепло встречали в Омске. Однокурсники с женами приехали. На вокзале - с цветами. Воронин Эрнест сказал: никаких гостиниц, никаких вопросов, будете жить у меня. Город изменился за эти годы - красивее стал. Когда я приезжал на 20-летие окончания института в 1979 г., приехало 98 выпускников. А в 2004 г. на 45 лет окончания института нас собралось всего 36 человек. Мы собрались сначала у корпуса своего мехфака, походили по его коридорам и аудиториям. Кстати, мне было особенно приятно увидеть на стенде, посвященном первому выпуску мехфака в 1954 г. фотографию нашего земляка - Манцаева Владимира Борисовича.

Нас пригласили в актовый зал института. Вел эту встречу наш однокурсник Подгорный Борис Николаевич. Потом к нам обратился с приветственным словом проректор института. Каждый о себе рассказывал. «Дай Бог всем здоровья дожить до золотого юбилея - 50 лет!», — как заклинание звучала эта фраза в устах каждого выступающего.
В один из дней нашего пребывания в Омске в 8 утра за нами приехали из Красноярки мои одноклассники - Николай Палецкий, староста класса, и Валентин Пономарев, наш комсорг. Здание школы, в которой мы учились, вернули под церковь. А школа располагается уже давно в центре поселка Красноярка в двухэтажном современном здании, которое было построено в свое время, кстати, моим другом и одногруппником - Ворониным Эрнестом Иннокентьевичем.

Хотона, в котором жили калмыки, уже нет. Конечно, там ведь одни землянки были. Мы с одноклассниками съездили на кладбище, на могилы учителей. Я им поклонился и поблагодарил их за всю их любовь к нам детям, оставшимся без отцов.

Я очень жалею, что в совершенстве не знаю свой родной язык, - меня это гнетет. Слушаешь дикторов, иногда не понимаешь, что они говорят. Потеряли мы родной язык. В этом Сталин виноват - так называемый «отец народов». Какой он отец, детей своих расшвырял, расстрелял, разбросал по миру.

\section{А. Н. Овшинов}

Свой род я практически не знаю. По молодости лет так, к сожалению, бывает, пока родители были живые, я этим не интересовался. Со слов родителей я знаю, что мой отец Овшинов Николай Джальдинович жил в Башанте вместе с мамой. Что было до этого, я не знаю. Они вдвоем остались. Он жил с мамой вдвоем в своем доме типа землянки, у них была кормилица-корова, как обычно. В один прекрасный день он решил эту корову продать. Он же хозяин, мама-то старенькая. Никто не мог понять, в чем дело, почему продать. А он решил стать фотографом и купить все принадлежности для этого. Кого-то нанял, тот его обучил, и он стал фотографом.

Мама моя Овшинова Номга (по-русски Вера) Манжиковна, 1902 г. р., была белошвея, работала в швейном цеху. Отец Микуш (по-русски Николай), 1897 г. р., закончил гимназию, работал товароведом. Был грамотным по тем временам. Отец был чоновцем, с бандитами воевал. Он прошел гражданскую войну, финскую войну, Отечественную войну. Теперь правнуки выносят его фотографию на Бессмертный полк. Он награжден медалью «За оборону Сталин- 
града», был ранен под Матвеевым курганом около Таганрога. Отец был разведчиком, а после контузии стал писарем. Сейчас я не могу проверить, все его документы - солдатскую книжку серого цвета, наградной лист - я собрал и сдал в республиканский музей.

Есть семейная фотография, мне недавно сестра рассказала. Оказывается, ему было настолько тяжело, что он решил попрощаться с нами: на оборотной стороне той фотографии написаны прощальные слова. А потом получилось так, что ему отпуск дали, и он приехал домой на несколько дней, Таганрог же рядом. Уже время подошло возвращаться. Еще с вечера собрал рюкзак, 28 декабря рано утром в 6 утра он пошел в военкомат. А ему там говорят: «Иди домой». — Как я пойду домой, чтобы меня под трибунал?» — «Ты иди, потом узнаешь».

Он вернулся, а тут пришли солдаты.

В Башанте всех собрали в школе. С одной стороны, нашей семье повезло - был мужчина. От того, что отец был с нами, повезло и другим. Вокруг были дети или старики. А потом к ним присоединился хромой мужчина. Я в то время был грудной, мне было где-то полгода. Пока сидели в школе и ждали транспорта, отец отпросился домой и успел оставшуюся живность (то ли хрюшку, то ли теленка) заколоть. У отца была такая предпринимательская, организаторская жилка. А уже вечером на «студебекерах» отправили в Сальск. А там - в теплушках в Ханты-Мансийск.

Я родился в 1942 г. У меня есть метрика на немецком языке. Родители ничего не говорили про оккупацию, вроде бы и немцев там не было. В 1943 г. старший брат Володя закончил школу, в Астраханское летное училище поступил. Но там, видимо, знали, что калмыков будут выселять. В это время шли эшелоны с ранеными. А его вызвали и сказали: «Мальчик, езжай домой». Чтобы выехать из Астрахани, он забинтовал себе ногу, вроде как бы раненый, и так приехал в Башанту.

На четыре года был младше второй брат Петр. Он школу не закончил, лодырь был, у него с учебой не получилось. Примерно на четыре года младше сестра моя Нина, 1935 г. рождения, училась в школе на момент выселения. После сестры иду я.
А я был из двойняшек. У меня был братишка Анатолий. Но его не стало до высылки еще. Как-то еще до высылки постарше которые возили его на тележке, уронили. Так что я теперь живу за двоих.

$\mathrm{y}$ родителей была швейная машинка «Зингер», мама гордилась ею, она отдала ее соседям. У отца было хорошее немецкое двуствольное ружье, тоже отдали соседям, сами. Ничего практически не смогли взять. В школе до вечера ждали эти «студебекеры», и отец сумел отпроситься, чтобы заколоть нашу живность, у нас то ли хрюшка была, то ли теленок. Ему пошли навстречу, он зарезал, и это мясо он взял с собой в дорогу.

В вагоне, кроме отца, был один больной мужчина, с ним подросток. Остальные все - женщины и дети. В основном сестра за мной ухаживала. В вагоне все же была буржуйка, нар не было. Солома была. В углу дырка вместо туалета. На окнах — решетка. Я всегда говорю, что выжил за счет молока матери. Братья бегали за кипятком, за водой и хлебом. Снабжали всех в вагоне. Когда подъехали к Омску, тот старик умер, у него оказался тиф. Некому было его из вагона вытащить, некому было похоронить, и вот отец и братья достали подводу и полностью возились с этим стариком, похоронили его. После этого два брата и сестра заболели тифом. Попали в больницу в Омске. Это мне мама не один раз рассказывала, я помню. Она все распродала, что можно было, все обменяла, чтобы в больницу носить передачи. Старший брат месяц с лишним валялся без памяти в больнице. Врач сказал: «Старшего вы, наверное, потеряете, надежды нет». Второй брат полегче болел, полмесяца всего, сестра еще легче перенесла.

А в это время в Омске... Вот как торопились с этой депортацией. Довезти-то довезли, а дальше в Ханты-Мансийск на пароходе надо четверо суток ехать. Помните фильм «Волга-Волга»? Там такой пароход с лопастями, вот на таком пароходе нам надо было четверо суток шлепать. К этому времени Обь замерзла, и дальше Иртыш замерз. Поэтому всех калмыков выгрузили и разместили в каком-то совхозе или колхозе. Только весной нас собрали снова и погрузили до конечной станции, это был Ханты-Мансийск. 
Нас привезли в Самарово, поселок на слиянии Иртыша и Оби, раньше ямщицкое поселение было. Когда всех разместили в школе, всем дали хлеб и головы муксуна. Там и муксун, и щука есть. Голова же - деликатес. Нас накормили.

Здесь были бараки построены. Там повсюду горы, между ними плато в 3 км. Здесь горы, низина, а здесь - деревянный тротуap, верх и вниз ведет, и дорога.

Я смутно помню, что мы жили в каком-то доме в низине. Помню, что в школу еще не ходил. Как-то брат средний очень поздно пришел домой и принес два таких красивых пугача. Отец на него рассердился, отобрал пугачи, открыл подвал и бросил туда их. А когда он открыл подвал, вода в подвале была под самую дверь. Это мы в низине жили. Рыбоконсервный комбинат находился внизу, калмыки там работали. А жили все наверху.

Сейчас у меня зрение плохое. Я же зрение потерял, я даже в армии не служил из-за этого. Там же в вагоне грязь, умыться нечем. Закутают от холода и все. У меня очень болели глаза. Через несколько лет болезнь проявилась. Я помню, утром проснешься, и на свет я не мог смотреть. Помню, мама занавесит одеялом окно, и я лежал так целыми днями. Мама рассказывала, что носила меня в больницу за 3 км вверх и вниз в Самарово. Я молча лежу на плече, как только подходим к больнице, начинаю орать. Ничего не видел, но чувствовал. Ничего не помогало. Однажды встретилась одна женщина, русская, что ли. Она спросила, и мама рассказала, что со мной. Она сказала: а вы попробуйте сахар измельчить и дунуть в глаза через трубочку прямо в глаза. Мама мне дунула. Ой-ой-ой! Жгло страшно. Но с тех пор глаза у меня больше не болели. Я жалею, что только два раза мне сделали. Надо было все же насильно в третий или в четвертый раз сделать. После этого мои глаза перестали болеть. До сегодняшнего дня не болят. Сколько я потерял зрение, на этом остановилось. С возрастом я хрусталик поменял. У меня утолщение роговой оболочки, вижу плохо. Это вот остатки той роскоши в Сибири... Очень мне помогла та женщина...

Первые воспоминания у меня связаны со школой. С 1-го по 4-й класс я ходил в эту школу. Мама-то у меня швея, она любую одежду перелицует и перешьет. Я был хоро- шо одет, как тут можно жаловаться? Всегда все подогнано по мне, я был чистенький, даже без заплат на штанах. Мама и фуражки шила для всех нас. Единственное, что мама обувь не шила. У меня была любимая собачка Сильва. Мы уехали, оставили ее родственникам.

Там была фотостудия, и хозяином был мой отец. Многие в Элисте мне говорили, что помнят это. Даже Кугультинов мне както сказал: «А ты знаешь, у меня есть фотография, которую твой отец снял».

Отец взял с собой увеличитель, штатив, коптилку, красный фонарь, ванночки. Помню, что сестра старшая просила у отца коптилку на новогодний вечер в школе, что второй брат стал помогать отцу. Они ездили по стойбищам хантов и манси и фотографировали их, привозили оттуда что-нибудь. В Ханты-Мансийске жили в основном высланные: мы, калмыки, татары, немцы и русские - из Москвы, из Ленинграда.

Первое время и отец с братьями, и мама должны были работать. Отца и старших братьев сразу отправили на лесоповал. Там холодно было зимой, под 40 градусов мороза, холодина. Однажды, помню, поздно вечером стук в дверь. Мы испугались. Оказывается, брат мой средний приехал домой на лыжах с лесоповала. Соскучился, видимо. Потом стало послабление.

Маме не разрешили работать по специальности, она же - «враг народа». И мама работала грузчицей на погрузке соли и рыбы на плашкоуте. Она утром уходила в фуфайке, приходила вечером поздно. Она была дородная женщина, ей лет 50 , наверное, было. Конечно, здоровье уже было не то, но что делать, заставляли.

Однажды мы ее долго ждали, есть хотелось, есть-то нечего было: ни чая, ничего нет. За работу маме давали чекушку сливок. Она в карман ее положит и приносит. Она пришла вся мокрая. Потом рассказывала она плохо говорила по-русски - что ее татарская девушка спасла. Шел дождь, она поскользнулась на мокром и упала в реку. Два раза она под воду уходила, а на третий раз фуфайка ее подняла наверх, и татарка смогла вытащить ее. Уже позже ей разрешили работать в швейной мастерской. Так что все работали.

У мамы была сестра, тетя Наташа. Ей, наверное, лет под 40 было. Она еще в Кал- 
мыкии работала связисткой, где-то в Цоросе. Она без семьи была, но со своим братом жила. Она работала мотористом на катере. Хорошая такая. Я ее помню. Тетя Наташа водила моторную лодку. Потом я узнал: якорь опускали, и она попала под цепь, обе ноги оторвало. Мы ее там оставили в Сибири.

Второй брат поступил в школу юнг, его оттуда выгнали, он хулиганом был. Потом он поступил работать на рыбоконсервный комбинат, там работал помощником моториста. Позже он начал учиться на шофера. Ездил на таких огромных машинах, как КРАЗ, которые на дровах работали. Выучился и стал профессиональным водителем, права получил там.

Старший брат в 1948 г. уехал в мореходное училище в Тобольске. Он получил диплом штурмана дальнего плавания на китобойных судах. Но ему не разрешили работать из-за того, что он калмык, и он получил вторую специальность капитана речного флота. Он был капитаном речного судна и ходил верх и вниз из Ханты-Мансийска по Оби и Иртышу. Он расчищал сплавы. Как-то он меня взял с собой. Он был занят своими делами. А я был сам по себе. И как-то упал в воду и наглотался мазута, приехал домой больной, желтенький весь. В Сибири он был единственный капитан — калмык.

Отец мой был хороший организатор. Он был в хороших отношениях с комендантом, и тот шел где-то навстречу. Он даже разрешил моей сестре поехать после окончания школы в Свердловск поступать в политехнический институт. Она на три «пятерки» и одну «четверку» сдала экзамены, прошла по конкурсу, но ее не зачислили, потому что она калмычка. Перед зачислением ее отправили домой.

Потом она поступила в институт сельскохозяйственных машин в Барнауле. Когда мы переехали сюда, она перевелась из Барнаула в Сталинградский политех. Она была единственный инженер-конструктор в Калмыкии. Научной степени у нее не было, но она преподавала в университете лет десять такие предметы, как ТММ (теория механизмов машин) или, как студенты говорят, «тут моя могила», и ДМ (детали машин). Это очень трудные дисциплины.

Учительница очень хорошая была. Брат учился в Тобольске и привез большие апель- сины, которые я видел тогда в первый раз. В тот же день я делал домашнее задание и торопился перед второй сменой. Поставил кляксу, стал стирать и стер до дыр. Я посмотрел на дыру и заклеил дырку. Тут же я схватил эти апельсины и от всей души решил подарить учительнице. Из самых хороших чувств ей отдал. А она поняла, что я хочу замолить дырку в тетради и всему классу показала дырку. Поставила мне кол, единственный в моей жизни. Но обидно было не за кол, а за то, что она так истолковала, что я этим своим подношением хотел замолить эту дыру в тетради.

По нации мы никого не различали. Все мы дружили. У меня был друг Саша Диулин. Мы с ним переписывались, а потом потерялись. Однажды мы решили, что я должен подраться со своим товарищем из класса. Все - человек 20 - собрались и пошли в лес. Там была такая поляна, на которой мы часто играли. Все окружили нас, и мы стали с ним махать кулаками. Никто друг друга не оскорблял, ничего между нами не было для драки. Мы были примерно равные по силам. Мне повезло, я ему разбил нос. Я сразу же побежал к ручейку, набрал воду и помогал ему обмыть нос. Потом мы обнялись и побежали в школу.

В пионеры я вступил, и это была большая честь. Впервые я там узнал, что такое пионерский лагерь. Как-то я в огороде вожусь, наверное, в 4 классе уже был, и папа у меня спрашивает: «Ты хочешь поехать в пионерский лагерь?». Конечно, хочется поехать. Поехали мы, человек 200 разных национальностей. Такие неприхотливые были. Нас, человек 200 детей, на баржу загнали: девочек в одну сторону, мальчиков - в другую. Одна молоденькая пионервожатая с девочками была. И мы несколько суток ехали без еды. Ни мама с собой не дала еды, ни там ничего. Даже воды не было, закрыли нас как узников, и мы молча ехали несколько суток. Молча сидим, спим. Открыли, когда приехали. Приехали куда-то, вокруг горы, лес. Мы снова на каком-то плато, внизу Обь. Несколько разбитых домов было, развернули столовую. Что-то вроде сцены соорудили. Баянист один был. Кормили нас. Жили мы в палатках, из увеселений тоже ничего не помню. Разве что был санитарный день. Все мы высыпали на берег Оби со своими грязными вещами. Мне особенно стирать 
нечего было. И сестренка была нашей снохи Светлана Бакинова, потом она работала адвокатом в Элисте. Я же не могу отстать от других, и я вытащил чистое и отдал ей стирать. Вот это я помню. Время подошло, нас забрали и повезли домой. Никаких проблем особенных не было, чтобы кто-то жаловался или дрался. Мы были все одинаковые, в поношенных одеждах, ходили гурьбой, все скромные.

Я был ударником, хотя пятерок было больше. Наша учительница Нина Леонидовна Вергунова старалась хороших учеников поощрить в конце четверти. Перед летними каникулами она лучшим ученикам по окончании учебного года дарила что-нибудь, например, по полметра сатина. Несколько раз я получал, мама мне рубашку сошьет, я бегаю в ней все лето. Благодаря отцу у меня был велосипед - вначале старенький, с него цепь всегда слетала, потом уже новый был.

Однажды зимой перед Новым годом учительница сказала четверым мальчикам пойти с нею и мне в том числе. Мне сказала взять санки, и я сбегал домой за санками, я недалеко жил. После уроков мы пошли на хлебокомбинат. Там для всех учеников нам дали по горячей булочке по количеству детей в классе. Мы их сложили на санки, завернули в одеяло. А нам дали по одной булочке дополнительно. Ведь как она продумала все, не просто кого-то взяла, а тех, кого хотела поощрить.

5 марта 1953 г. для меня был темный-темный день. Знаете, почему? Урок физкультуры должен был быть. Я учился в 3 классе. Мы же с утра до вечера на лыжах зимой. Утром, если с вечера не сделал, быстро уроки сделал и сразу на лыжи до обеда. В обед прибежал, поел и в школу. Урок физкультуры должен быть первым. С утра ждал я этого урока. Ждем-ждем, уже на лыжах стоим на горке, а преподавателя нет. Не дождались, поехали в школу, и там узнали. Все плачут. Урок физкультуры сорвался, изза этого я запомнил. Нам сказали, чтобы мы траурные ленточки прикрепили к галстуку. Чтобы дети плакали, я не видел, и в семье у нас никто не плакал. А вот жена моя рассказывала, что в их семье мама и сестра, все ревели. Тут пришел отец ее, мой тесть, я его не видел, он в Сибири остался, его бревном придавило, он там умер. И он им сказал: что вы плачете? Пройдет немного времени, и мы вернемся все домой в Калмыкию. Как он мог такое знать? Предчувствовал, наверное.

Про политику у нас в семье не разговаривали. А я был огорчен, что урок физкультуры пропал. Дома говорили все время по-русски, мама с папой между собой по-калмыцки. В наших местах калмыки говорили по-русски, а вот в Красноярском крае, где моя супруга была, где жил Алексей Балакаев, другие наши артисты, там калмыки между собой по-калмыцки говорили. Там они сцену оборудовали, ставили концерты и спектакли.

Вот мои братья рассказывали, что они собирались на вечеринки, но все говорили между собой по-русски и по-калмыцки не танцевали и не пели. Сказывалось все-таки, что Городовиковский район - Западный улус - по-русски хорошо говорили. Моя жена хорошо говорит по-калмыцки, она и поступила учиться [на калмыцкое отделение], а я все понимаю, но не говорю. Когда мы вернулись, мы изучали калмыцкий язык между сменами, но какой там язык.

Дома какие-то праздники мама отмечала. Она борцыки жарила - в виде солнца, лодки, зажигала лампадки. Зажигала спички. Что это, какие именно праздники, я не знаю. Но мама, видимо, знала, про себя молилась, но не рассказывала нам.

Я запомнил такой праздник в Ханты-Мансийске, как День песни. Из Самарово до Ханты-Мансийска пять километров. Мы ездили туда на День песни на целый день. На стадионе. Впервые я видел там хор. На столах продавали книги. Папа мне дал денег, я долго выбирал и выбрал почему-то «Герой нашего времени». Там и буфет был. Люди всегда ждали этого праздника.

Внизу был рыбный клуб. Туда ходили старшие. А мы по воскресеньям туда ходили в кино. С 2 часов шло кино. Один мальчик собирал у нас деньги и стоял в очереди. Очередь в кассу не стояла в линию в затылок, там все толкались. Он всегда нам покупал. А мы в это время играли.

Помню один фильм так заканчивался: победа наших под Сталинградом, на подводной лодке приплывает Сталин, выходит и закуривает трубку. Несколько раз я смотрел фильм про какого-то композитора, но не Чайковского. Оно нужно нам было? Но мы не выбирали, что шло, то и смотрели. 
Мы играли в лапту, в футбол тряпичным мечом, в обруч бегали наперегонки, на ходулях наперегонки. Это были наши игры, хорошие игры. А старший брат на мандолине и на баяне хорошо играл, а его жена - на гитаре.

Я был самый любимый в семье, и меня никто не заставлял делать домашнюю работу. Но я помню, что я и сажал картошку, и собирал ее. Сестра носила воду ведрами на коромысле, примерно километр надо было идти по неровной дороге. Если воды нет, топили снег. Я тогда маленький был, видно меня жалели. Сестра с братом дрова рубили, меня не допускали, все-таки опасно. Дома меня все называли Лёня, так пошло от старшего брата, у которого лучший друг детства в Башанте был русский парень Лёня. И вот он меня все-время Лёня называл. А пишусь я Алексей. Сын мой внука тоже назвал Алексей.

Наши где-то в апреле поехали в Калмыкию. Внизу, недалеко от школы пристань. Конечно, провожали их, гуляли основательно, пили все, провожали. Я был на уроках, никогда не пропускал и побежал проститься. Они уехали, меня оставили до окончания учебного года с маминым братом и гагашкой. Школу я закончил, и гагашка неграмотная меня повезла.

Ехали мы домой с братьями Курнеевыми, Сергеем и Володей, они младше меня. Они с бабушкой Анисьей и я. Какие мы все были санамр (здесь: жили одним днем). До сегодняшнего дня у меня в голове не умещается. Как можно так было ехать четверо суток. Понятно, денег нет, купили самый дешевый билет, и не плацкарт, а вообще место не указано. Где будет место, там можно прикорнуть. Прямо на палубе нашли место поближе к двигателю, чтобы теплее. Взяли они какое-то одеяло, расстелили. А палуба, чтобы не скользить, вся в шишках. Вот сверху постелили тонкое одеяло. Четверо суток так пролежали. Кушать ничего нет, ни та бабушка, ни моя не подумали. Ведь можно было же взять с собой картошку вареную, ничего не взяли. Однажды в Тобольске остановка была где-то в 12 ночи. Бабушки говорят: ты за ними смотри, мы спустимся, посмотрим, может, продукты найдем. Конечно, ничего не нашли. Вот так и привезли нас в Тюмень.

В 1955 г. вся наша семья выехала оттуда. Брат уже жил в Тюмени, и мы поехали к нему. Там жила тетя Саня Кичикова со своими братьями. У нее был неплохой дом, сарай, кухня. Мы там жили у них. Тетя Саня была медработник. Мы прожили еще год в Тюмени, я ходил в школу, в 5 класс. Мне рельсы были в новинку, я по ним ходил само собой. А шпалы руками трогал, они новенькие были, обмазанные смолой, видно, запах сосны такой вкусный был.

А потом из Тюмени мы поехали в Казахстан. Там мы жили в Каскиленском районе, это запад Казахстана, примерно 100 км от Алматы. Нас туда пригласил Манцынов Басан Омбукович, он считается племянником моего папы. Он тогда в профсоюзах работал. Его жена Тася работала заведующей детским садиком. Вначале они кибитку развернули, потом они жили в половинке финского домика. Я там учился в вагоне: с одной стороны мы жили, с другой стороны - школа. В Казахстане я увидел впервые многое, чего не было в Сибири: змей, цесарку, фрукты и т. д.

Потом уже приехали сюда, в Элисту, я пошел в 1-ю школу. Через месяц родители решили ехать на родину в Башанту. В Башанте я запомнил пыльные бури. Я всегда в чистой белой рубашке ходил. Пока придешь в школу, она уже серая, сам весь грязный. Учился в старой школе. Закончил ее в 1960 г.

Отец был беспартийным, а старший брат у меня был коммунист, я и сестра тоже были коммунистами. Меня принимали здесь в школе. Я с большим энтузиазмом вступал. Когда мне предложили, я сразу согласился. Тогда на учителей, на интеллигенцию давали очень мало мест. Каким образом школе дали это место? Я тогда в седьмой школе работал. Меня пригласил секретарь партийной организации Кантемиров Сергей, отчества не помню, русский. Так конфиденциально меня завел в кабинет директора, посадил. Я думаю: что я натворил? Говорит: мы решили Вам предложить... Я сразу согласился и всегда гордился этим. Потом я же в Элисте освобожденным секретарем работал три года...

Чем становишься старше, тем воспоминания становятся рельефнее. Наверное, это у всех так. Там, где мы жили, не могу сказать, чтобы кто-то меня прессовал. Только один раз математичка сказала мне чтото обидное, связанное с национальностью, обозвала меня. Больше таких случаев не 
было. Ну, был еще один, но другой. Я в школе на перемене стоял у окна вполоборота, о чем-то задумался и не заметил, как мимо проходил директор. Он меня сильно обидел, так отчитал. Он, видно, подумал, что я не захотел поздороваться. Мы были приучены на морозе, даже 30-градусном, снимать шапку перед учителями. До сих пор, как захожу в помещение, я снимаю головной убор.

Я был маленький. Но те, кто учился в ремесленном, они обзывали парней-калмыков, задирались. Были случаи, что и дрались. Я помню дразнилку тех лет: «Калмык с котелком, ты куда шагаешь? В райком за пайком, разве ты не знаешь?». А тогда были большие консервные банки, и иногда давали что-то вроде жмыха, остатки пережаренной рыбы в масле. Сестра рассказывала, как она несла хлеб по талонам. К брату Петру на танцах придрался высокий русский парень, наверное, из-за девушки. А Петр был хулиган и поддержку чувствовал, но он засадил в глаз ему и поставил синяк. Так вот я помню, что лежу на печи и заходит тот парень с отцом и хотят получить сатисфакцию за синяк. Отец, кажется, согласился заплатить.

Как-то в школе нам дали несколько приглашений на новогоднюю елку в Ханты-Мансийск. И я ходил. Целый день там лазил. Моя учительница не посмотрела, что я калмык. Она тоже была депортированная, ее отец был священником. Она, оказалось, была орденоносцем, у нее был Орден Ленина.

Позже я три раза был в Ханты-Мансийске: в 2002 г. Поездом Памяти, потом с делегацией калмыцкого Хурала, потом с женой в 2013 г. Меня тянет туда. Там никого у меня нет, просто хотелось посмотреть.

Когда я ездил Поездом Памяти в 2002 г., я был одним из руководителей Поезда. Этот поезд шел в Тюмень, Омск, Томск и до Красноярска. Меня попросили в Тюмени выступить. Организация поезда была хорошая. Некоторые заранее выехали и организовали, чтобы могилы привести в порядок. Поезд остановился: полный вокзал, столько людей! Русские, калмыки - все, кто узнал, все пришли. Руководство, оркестр. Мне дали слово, и я выступил. Заранее я не готовился, а спонтанно выступил, и мне захотелось рассказать об учительнице. Я рассказал о ней, назвал имя-отчество, высказал благодарность. Потом мы целый день ездили по кладбищам. Нас же 500 человек было в поезде. Автобусов было много, больше десяти. Погода хорошая, но как подъезжаем к кладбищу, начинает дождь моросить. Садимся в автобус, солнце выходит. И так несколько раз. Как будто специально кто-то кран включает-выключает.

В одном месте ко мне подходят две девушки и просят дать интервью для одной тюменской радиостанции. Вы не могли бы поделиться своими воспоминаниями? Ну, я рассказал про учительницу. Я в Тюмени учился в 5 классе. Вечером у нас был большой прием в администрации города в таком большом зале. С нами ездили «Ойраты», они выступать должны были. В это время ко мне подходят и приглашают к телефону. Я удивился: кто меня может здесь знать? Оказалось, что мое выступление слышал внук моей учительницы Анатолий. А я и не знал, что у нее есть внук. То, что три внучки есть, знал. Он, оказывается, уже давно живет в Тюмени, предприниматель по линии искусства. Он в тот день приехал из командировки, включил телевизор и услышал, что говорят о его бабушке. Мы договорились встретиться. Вечером мы вернулись к 11. Анатолий такой довольный пришел, с супругой, выселенной немкой. Имени не помню, отчество Генриховна. Понимаете, как бывает в жизни? Мы потом долго переписывались, а потом он уехал в Германию, и мы потерялись. Жаль.

\section{Дети Сибири. Комментарии}

Валерий Бадмаев и Алексей Овшинов родились в полных калмыцких семьях: Валерий был вторым сыном у Бадмаевых, Алексей - младшим, четвертым сыном, как говорится у калмыков - был последышем (отхн көвүн) - в семье Овшиновых.

Их отцы относились к тем калмыкам, кто боролся за Советскую власть, разделял ее ценности и отстаивал с оружием в руках в годы Великой Отечественной войны. В обеих семьях доминировали модернизированные семейные отношения, в которых женщина имела свою профессию и могла зарабатывать своим трудом. Особенно это относится к семье Бадмаевых, которые несколько предвоенных лет жили в Москве. Дети Бадмаевых и Овшиновых росли, социализируясь в советской школе, говорили дома по-русски, не были религиозны и не практиковали дома религиозные ритуалы. 
Когда началась Великая Отечественная война, Ишля Манджиевич Бадмаев, будучи преподавателем в Институте красной профессуры, имел право на бронь - и как ценный сотрудник, и по медицинским показаниям как человек с сильной близорукостью (диоптрии были: -7 и -8). Но уже в первый военный месяц Ишля Манджиевич записался в ополчение и поехал защищать Ленинград с полком ополченцев - преподавателей московских вузов, их состав разбомбили, они не доехали до линии фронта. Нямиш Шургановна получила извещение, в котором было написано, что И. М. Бадмаев пропал без вести.

Родители рассказчиков носили калмыцкие имена, как большая часть калмыков. Трое детей Бадмаевых были названы не калмыцкими именами, а в соответствии с духом эпохи. И. М. Бадмаев назвал первенца в честь своего любимого поэта - Генриха Гейне, второго сына - в честь Валерия Чкалова, который незадолго до рождения В. И. Бадмаева совершил свой беспосадочный перелет из СССР в США. Младшая дочь Бадмаевых, родившаяся в 1939 г. в Москве, получила испанское имя Кармен в знак солидарности с испанским народом и его республикой, но позже ее стали звать по-калмыцки Кермен. Нямиш Шургановна стала для своих сибирских учеников Ниной Шургановной.

Стали отзываться на русские имена и старшие Овшиновы. Номга Манжиковна для сибиряков стала Вера, Микуш Джальдинович Овшинов - Николаем. Овшиновы также в свое время выбрали для детей русские имена: Володя, Петр, Нина, Алексей и Анатолий и этим облегчили их жизнь в Сибири.

Как начинает свой рассказ А. Н. Овшинов, свой род я практически не знаю. Это признание могли бы разделить многие его ровесники. Родители часто не рассказывали детям о своих предках, потому что всегда были заняты работой, не считали это особенно важным, может быть, ждали, когда дети подрастут, а также и особенно тогда, когда не хотели, чтобы дети располагали семейной информацией, которая могла бы им помешать в жизни. Высока вероятность, что среди предков Овшинова были те, кто относились к социально враждебным слоям - зайсангам (калмыцкой аристократии), зажиточным крестьянам, скототорговцам или духовенству, потому мы и наблюдаем провал в памяти, провал в знании: кто были предки, чем занимались? Табу на нежелательное прошлое длилось, может быть, 40 лет, но его результат продолжает сказываться, и о молчании своих прадедов сожалеет современная молодежь.

В. И. Бадмаев признается, что детство свое помню очень плохо, в основном только со слов нашей мамы. Да и она не очень охотно вспоминала... Возможно, что травматические события блокировались в памяти на некоторое время. И антропологи называют период в 30 лет, как необходимый для преодоления травматического события [Ассман 2014: 25]. Но для этого также нужны и благоприятные социальные условия. Калмыки стали рассказывать о депортации в конце 1990-х гг. не просто потому, что прошло 30 лет с тех пор, как они вернулись на родину. Это стало возможным потому, что политика партии в то время стала либеральнее, а Закон 1991 г., признавший депортации народов преступными актами, легитимизировал воспоминания о годах депортации и задал тренд на виктимизацию воспоминаний.

Однако какие-то воспоминания о раннем детстве сохранились, потому что мама не один раз рассказывала. Это свидетельство, что остается в памяти следующего поколения крепко, то, что рассказывается старшими многократно. В данном примере Н. М. Овшинова рассказывала о самом тревожном моменте: как по дороге в места выселения заболели все старшие дети тифом и лежали в инфекционной больнице Омска, и как врачи готовили родителей к худшему развитию событий.

Ранние воспоминания В. И. Бадмаева связаны с эвакуацией из Элисты в Астраханскую область летом 1942 г. Перед нами предстают почти кинематографические кадры: немецкий самолет, смеющееся лицо летчика, которому нравится, как напуганы люди и скот, и совсем некинематографическое продолжение: 4-летний мальчик, схвативший туфлю и убежавший в степь.

Первые воспоминания А. Н. Овшинова связаны со школой. Речь идет об осознанных воспоминаниях, о становлении субъектности. Стоит отметить и мудрую учительницу у А. Овшинова, которая находила возможности для поощрения при- 
мерных учеников, создавая в классе атмосферу добра и справедливости. Недаром так долго длятся контакты с ней и ее внуками. Но помнит своих школьных учителей и В. И. Бадмаев: как «всю поэзию» при дефиците книг читал по памяти учитель русской литературы Михаил Трофимович Мишин, как любовь к математике взрастила в учениках Анна Николаевна Игнатенко, как уроки немецкого языка вел Маевский Роберт Карлович, тоже репрессированный, волжский немец. Эта благодарность школьным учителям, и прекрасно знавшим свой предмет, и уважавшим своих учеников - характерная черта для памяти многих калмыков.

Удивительна история о том, как отец рассказчика Микуш Овшинов незадолго до войны продал свою корову, кормилицу семьи, и освоил новую специальность фотографа. Этот судьбоносный выбор был не просто удачей, был не только своевременным решением умного человека с хорошей интуицией. Он отражает начинавшийся разворот народа от аграрной экономики, от крестьянского хозяйства к модерной экономике, к городской культуре и городским профессиям, который начинался тогда, когда люди сами определяли свой выбор, а не когда его подсказывали власти.

Хороший организатор, каким он запомнился сыну, Микуш Джальдинович, видимо, хорошо чувствовал время и хотел жить в ногу с ним. Жизнь показала верность его выбора - и потому, что весь частный скот остался в Калмыкии, а фотоувеличитель и фотоаппарат вполне можно было увести с собой и создать свое дело в новом месте. Работа фотографа была социально востребована, фотографии были нужны и гражданам, и государству. Более того, специфика работы предполагала смешанные формы собственности, в которых успех предприятия во многом зависел от инициативности и других личных качеств владельца. Даже в эпоху жесткого тоталитаризма находилось пространство для экономической многоукладности - пусть точечное, пусть в очень отдаленном месте.

В нарративе А. Н. Овшинова не раз подчеркивается грязь как имплицитный знак опасности. Соответственно, грязнее всего / опаснее было в вагоне, увозящем людей в Сибирь. Грязь трактуется в антропологии как «то, что не на своем месте» [Дуглас 2000: 65].
В данном смысле все было не на своем месте: и люди были не у себя дома, в скотских вагонах, не предназначенных для перевозки людей, не в больницах были больные, и живые люди ехали вместе с умершими. Кроме такого символического толкования, существуют и более конкретные определения нечистого, связанного с жизнедеятельностью человека. Небольшое пространство вагона, тесное для 40 человек, в центре которого была печь, для которой надо было добывать топливо на остановках, а если она топилась, на нее можно было упасть при резком торможении и обжечься, щели в стенах и полу вагона, из которых дуло представляли опасность символически и реально. Именно грязь вагона, в котором в течение трех недель было невозможно толком вымыть руки или умыться, и видится причиной проблем со зрением у маленького Лёни.

Когда страхи первых лет ушли и зрение у мальчика наладилось, жизнь налаживалась, и рассказчик это время маркирует чистотой в одежде, которую с любовью ему шила мама. В его нарративе мы встречаем уточнение: $я$ был «чистенький». Это подтверждение того, что опасности уже не угрожают.

Любовь и уважение к матери А. Н. Овшинов выражает то, как он называет ее профессию: белошвея. В русском языке нет такого слова, есть близкое - белошвейка, которая отличается от швеи своей специализацией: она шьет белье - постельное и нижнее. В калмыцкой традиции все женщины умели шить - кто-то лучше, кто-то хуже. А профессиональные портнихи обычно не имели узкой специализации и шили все, что требуется - от нижней одежды до верхней. Нежное отношение к матери А. Н. Овшинов передает несуществующим обозначением профессии, видимо, отказываясь от суффикса «к», который часто имеет оттенок небрежности и смущал рассказчика.

Важный вопрос, который поднимает В. И. Бадмаев, ставший особенно актуальным в последние годы, - вопрос о героизме калмыков, участников Великой Отечественной войны. Статистика, которую приводит Валерий Ишляевич, относится к советскому периоду истории. Но постперестроечные открытия в области военной истории дали новые сведения о калмыках - 
Героях Советского Союза: во-первых, их количество пополнилось именем Э. Л. Бадмаева, который был представлен к званию Героя Советского Союза в сентябре 1945 г. Но присвоено звание Героя Советского Союза с вручением ордена Ленина и медали «Золотая Звезда» (№ 11604) Э. Л. Бадмаеву было только указом президента СССР от 5 мая 1990 г.

Стали также известны имена героев, которые были представлены в 1944-1945 гг. к званию Героя, но из-за пункта о национальности после указа от 27.12.1943 были награждены другими орденами. Таких героев-калмыков, чьи представления на звание Героя Советского Союза были доказаны, восемь [Очиров 2019: 187], но наградить их по тем же представлениям оказалось невозможным.

Как и в каждом спонтанном рассказе, мы замечаем, какие новые нюансы появляются в повествовании о своей судьбе, и встречаем то типичные языковые формулы для калмыцкого нарратива о Сибири, то, наоборот, редкие, свойственные только этой биографии, подробности. Все важно для исследования, остановимся на некоторых из них.

А. Н. Овшинов рассказывает о дороге в Сибирь: в теплушках в Ханты-Мансийск. Вновь замечаем, какая ирония заключается в том, что неотапливаемые вагоны железнодорожного состава были названы теплушками. Обратим внимание, что в Ханты-Мансийск невозможно добраться по суше, в теплушках, но для рассказчика Сибирь - это в первую очередь локус, в котором он провел свое детство, - Ханты-Мансийск, поэтому он так и обозначает маршрут.

Вокруг были дети или старики. А потом к ним присоединился хромой мужчина. В этом нарративе не раз проявляется демографический дисбаланс высланных: здоровый мужчина на весь вагон был только М. Овшинов. Если учесть, что по переписи 1939 г. калмыков насчитывалось 134 тыс. чел. [ВПН 1992: 65], а в Красной Армии служила 21 тыс. калмыков из республики [Максимов 2010: 344] и 4,6 тыс. калмыков - жителей других областей [Очиров 2019: 175].

По подсчетам У. Б. Очирова в Красной армии служил каждый пятый калмык, т. е. «почти все взрослое мужское население» [Очиров 2019: 175].
В образе хромого мужчины мы видим символ ущербной маскулинности калмыцких мужчин 1944-1945 гг., которым отказали в праве носить оружие и сослали в трудовой лагерь. Не доехал этот хромой инвалид до Сибири, как не доехали к своим семьям многие широклаговцы. Образы инвалидности проявляют язык травмы, который отражает самочувствие репрессированного человека как беспомощного, как неполноценного в своих правах.

Приведенные в рассказе несчастные случаи также формируют язык травмы: упала Н. М. Овшинова в реку и спаслась благодаря проходившей мимо татарке и тулупу, который не дал утонуть. Падал в реку и сам Леня, наглотался мазута. Самый трагичный случай: упала тетя Наташа и попала под якорную цепь, потеряв обе ноги, - стихия воды как стихийное бедствие для степняков подстерегает в незнакомой, чуждой природе Сибири.

Часто калмыки избегают лексики, связанной со смертью, применительно к членам своей семьи. Так, А. Н. Овшинов говорит: оставили в Сибири или он в Сибири остался, его бревном придавило. Вместо выражения «похоронили» автор использует эвфемизм, который смягчает оценку трагического события. Это в целом соответствует буддийскому отношению к переживаемому событию, изменить которое человеку не дано. Хотя наши бабушки все время молились - мы слышим эти слова от рассказчика не о своей конкретной бабушке, а в целом - о старшем поколении. Не кто-то конкретно и явно, а в целом бабушки создавали такую атмосферу, в которой не стоило стенать и роптать на судьбу, а надо было жить и работать, надеясь на лучшее. Это не прямое, а косвенное влияние старшего поколения, которое свое буддийское мировоззрение растворяло в этике терпения, милосердия и сострадания, что не было опасным для внуков, пионеров и комсомольцев, не было чревато и для детей-коммунистов.

Стигматизованность принадлежности к калмыцкому народу отразилась в стигматизации на первых порах калмыцкой культуры, часть которой, связанная с верой и с калмыцкими календарными праздниками, имевшими буддийские элементы в толковании и ритуале, ушли в приватную сферу. Как рассказывает А. Н. Овшинов, какие 
именно праздники, я не знаю. Но мама, видимо, знала, про себя молилась, но не рассказывала нам. Не случайно из всех праздников детства ему больше всего запомнился День песни в Ханты-Мансийске.

Как рассказывает В. И. Бадмаев, там $u$ поселились мама, наша слепая старенькая бабушка и нас, трое детей. В этом нас винительном падеже вместо именительного - отражается язык травмы и его прагматика, выражающая объект действия, а не его субъект. Маленькие трое детей - в воспоминании Бадмаева - не $M b l$, а нac, ведь выселяли, отвозили на станцию, перевозили в вагоне, распределяли на жилье - нас.

Ярким воспоминанием о первой зиме осталось, что калмыки копали это поле, искали остатки мерзлой картошки. Мерзлая картошка - не человеческая еда. Если она могла быть применима в качестве пищи, то только для домашних животных. Язык травмы актуализирует эту кризисную еду, тем самым показывая статус высланных калмыков как близкий статусу животного. И удивительная детская память помнит лепешки из мерзлого картофеля как самую вкусную еду в жизни.

Травматическая память всегда фиксирует нехватку: в Сибири это было нехватка родины, своего дома, своего скота, нехватка свободы - свободы передвижения, свободы в решении своей судьбы в выборе образования и проч.

Спустя годы травмировать стало то, о чем в Сибири не задумывались, - незнание родного языка. Как признается А. Н. Овшинов, а я все понимаю, но не говорю. Когда мы вернулись, мы изучали калмыцкий язык между сменами, но какой там язык.

В. И. Бадмаев также признается: Я очень жалею, что в совершенстве не знаю свой родной язык, - меня это гнетет. Слушаешь дикторов, иногда не понимаешь, что они говорят. Травма проявляется здесь нехваткой родного языка, без которого позитивная самооценка у человека неполная. Через вопрос о знании родного языка создаются социальные, культурные и моральные границы своих и чужих, «правильных» калмыков и «неправильных».

Хотя вопрос о том, что читали дикторы, также требует изучения: калмыцкий идеологический язык общественно-политических газет и телевидения часто был искусственным, «деревянным», как говорят калмыки. Часто это были тексты, которые писались по-русски и переводились на калмыцкий язык. С помощью вопроса о языке очерчиваются темпоральные границы будущего (неужели народ перейдет на другой язык?) и прошлого (золотого века, когда все свободно говорили и писали на калмыцком языке).

Хотя оба собеседника безоговорочно признают родиной Калмыкию, для детей Сибири малой родиной остается тот ее уголок, в котором прошло детство. Недаром каждый из них не раз съездил во взрослом возрасте в те места: Позже я три раза был в Ханты-Мансийске: в 2002 г. Поездом Памяти, потом с делегаџией калмыцкого Хурала, потом с женой в 2013 г. Меня тянет туда. Там никого у меня нет, просто хотелось nосмотреть.

В. И. Бадмаев также не раз посетил Омск и Омскую область, чтобы встретиться с одноклассниками и однокурсниками: $B$ ceмье мы часто вспоминали и до сих пор вспоминаем Сибирь, там же детство и юность прошли. Друзей много там осталось.

Разные по жизненным обстоятельствам два моих собеседника были вторым поколением советских калмыков, а относительно депортационного периода их можно отнести к одному поколению «детей Сибири». Ровно как родители, они были ограничены в своих правах и не могли свободно выбирать профессию и вуз обучения, но в отличие от родителей они активнее реагировали на большое общество, стараясь лучше учиться и быть не хуже других - в своей мальчишеской кампании, в спорте, в школьном хоре.

Они оказались на дистанции от многих калмыцких традиций и даже языка, потому что советская молодежь была увлечена идеалами всего человечества. Они вернулись в Калмыкию, привыкали к ней, включая и пыльные бури, от которых рубашка становилась серой прямо с утра. Приписанная родина стала настоящей степной родиной, но и Сибирь не дает забыть о себе. В терминах Дж. Александера рассказы В. И. Бадмаева и А. Н. Овшинова можно считать прогрессивными, депортация и незаслуженное обвинение народа было воспринято как «историческое распутье, которое постепенно будет преодолено» [Александер 2013: 164]. Годы 
депортации были позитивно пережиты в предложенных интервью представителей «детей Сибири», потому что они и были

\section{Литература}

Александер 2013 - Александер Дж. Смыслы социальной жизни: культурсоциология / пер. с англ. Г. К. Ольховикова; под ред. Д. Ю. Куракина. М.: Праксис, 2013. 639 с.

Ассман 2014 - Ассман А. Длинная тень прошлого. Мемориальная культура и историческая политика / пер. с нем.: Б. Хлебников. М.: НЛО, 2014. 323 c.

ВПН 1992 - Всесоюзная перепись населения 1939 года. Основные итоги / сост. Ю. А. Поляков, В. Б. Жиромская, А. А. Исупов, И. Н. Киселев. М.: Наука, 1992. 256 с.

Гучинова 2005 - Гучинова Э.-Б. М. У каждого своя Сибирь: Два рассказа о депортации калмыков // Антропологический форум. № 3. 2005. C. 400-442.

Гучинова 2019 - Гучинова Э.-Б. М. У каждого своя Сибирь. Две истории о депортации калмыков (интервью с С. М. Ивановым и

\section{References}

Alexander J. The Meanings of Social Life: A Cultural Sociology. G. Olkhovikov (transl.). Moscow: Praxis, 2013. 639 p. (In Russ.)

Assman A. The Long Shadow of the Past: Memorial Culture and Historical Politics. B. Khlebnikov (transl.). Moscow: NLO, 2014. 323 p. (In Russ.)

Douglas M. Purity and Danger: An Analysis of Concepts of Pollution and Taboo. Moscow: Kanon-Press-Ts, Kuchkovo Pole, 2000. 281 p. (In Russ.)

Guchinova E.-B. M. 'Everyone has one's own Siberia': Two stories of the Kalmyk Deportation (interviews with S. M. Ivanov and S. E. Naranova). Oriental Studies. 2019. No. 3. Pp. 397-422. (In Russ.) DOI: 10.22162/2619-0990-2019-433-397-422

Guchinova E.-B. M. Everyone has his/her own Siberia: Two stories about the deportation of травмированы меньше, чем их родители, и в целом судьбы этих семей сложились относительно благополучно.

С. Э. Нарановой) // Oriental Studies. 2019. № 3. C. 397-422. DOI: 10.22162/2619-09902019-43-3-397-422

Дуглас 2000 - Дуглас М. Чистота и опасность. Анализ представлений об осквернении и табу. М.: Канон-пресс-Ц, Кучково поле, 2000. $281 \mathrm{c}$.

Максимов 2010 - Максимов К. Н. Великая Отечественная война: Калмыкия и калмыки. Изд. 2-е, доп. и испр. М.: Наука, 2010. 406 с.

Очиров 2019 - Очиров У. Б. Жители Калмыкии - военнослужащие Красной Армии, представленные, но не награжденные «Золотой звездой» // Magna adsurgit: historia studiorum, 2019. № 2. C. 174-188. DOI: 10.22162/2541-9749-2019-8-2-174-188

Шевенова, Гучинова 2005 - Шевенова С. И., Гучинова Э.-Б. Память в наследство. Депортация калмыков в школьных сочинениях. СПб.: Алетейя, 2005. 228 с.

Kalmyks. Forum for Anthropology and Culture. 2005. No. 3. Pp. 400-442. (In Russ.)

Maksimov K. N. The Great Patriotic War: Kalmykia and Kalmyks. $2^{\text {nd }}$ ed., rev. and suppl. Moscow: Nauka, 2010. 406 p. (In Russ.)

Ochirov U. B. Red Army servicemen from Kalmykia and the Gold Star medal: the singled out but never awarded ones. Magna adsurgit: historia studiorum. 2019. No. 2. Pp. 174-188. (In Russ.) DOI 10.22162/2541-9749-2019-82-174-188

Polyakov Yu. A., Zhiromskaya V. B., Isupov A. A., Kiselev I. N. (comps.) The Soviet Census of 1939: Main Results. Moscow: Nauka, 1992. 256 p. (In Russ.)

Shevenova S. I., Guchinova E.-B. The Inherited Memory: Kalmyk Deportation in Schoolchildren's Essays. St. Petersburg: Aletheia, 2005. 228 p. (In Russ.) 